\title{
Morphometric characteristics and hydrological dynamics in micro- basins with different land uses of cerrado soils in Mato Grosso
}

\author{
Características morfométricas e dinâmica hidrológica em \\ microbacias sob diferentes uso do solo do cerrado Mato-Grossense
}

\author{
Wellington de Azambuja Magalhães ${ }^{1 *}$; Ricardo Santos Silva Amorim²; \\ Maria O’Healy Hunter ${ }^{3}$; Edwaldo Dias Bocuti ${ }^{1}$; Tulio Gonçalves dos Santos ${ }^{1}$
}

\begin{abstract}
Highlights:
Land use contributes to ecosystem stability in the cerrado biome. Micro-basins with sandy soils show greater regulation of runoff.

Land use change from native vegetation to pasture alters the hydrologic regime of the micro-basin. Micro-basins with clayey soils show greater extremes of water retention.
\end{abstract}

\begin{abstract}
Understanding the hydrologic regime, and monitoring runoff at the micro-basin scale is critical for understanding water availability, and for managing water resources in strategic biomes such as the cerrado. The objective of this research is to evaluate morphometric characteristics and the hydrologic regime and determine their relationships with soil characteristics and typical land-use in the cerrado biome. To reach this objective morphometric characterization, runoff and precipitation monitoring, and determination of the water retention curve were conducted in three micro-basins in the municipality of Campo Verde, Mato Grosso. These micro-basins each have a different, but regionally typical landuse and were selected strategically to represent this area of cerrado: agriculture, pasture and native vegetation. The results obtained allow for the analysis of the hydrologic regime throughout the period measured. Micro-basins with native vegetation and pasture, with greater altimetric range and more sandy soils, show greater erosion. Despite this, the micro-basin with pasture cover showed greater regulation of runoff. The micro-basin with agriculture showed less regularization of water flux due to the physical characteristics of the local soils.
\end{abstract}

Key words: Hydrologic behavior. Turbidity. Basin-scale management. Land-use.

\section{Resumo}

O conhecimento e monitoramento da vazão, assim como o entendimento do regime hidrológico a nível de microbacias tem sido relevante para se determinar a disponibilidade hídrica, assim como promover o gerenciamento dos recursos hídricos em biomas considerados estratégicos como o cerrado. Este trabalho foi desenvolvido com o objetivo de avaliar as características morfométricas e o regime hidrológico e sua relação com as características do solo bem como do seu uso em três microbacias no bioma cerrado. Para alcançar o objetivo proposto, fez-se a caracterização morfométrica, o monitoramento da vazão e da

1 Bolsistas CAPES, Curso de Doutorado do Programa de Pós-Graduação em Agricultura Tropical, Universidade Federal de Mato Grosso, UFMT, Cuiabá, MT, Brasil. E-mail: wellingtonagro@gmail.com; ed.bocuti@hotmail.com; tuliogsantos@hotmail.com

2 Prof. Associado IV, Departamento de Engenharia Agrícola da Universidade Federal de Viçosa, DEA/CCA/UFV, Viçosa, MG, Brasil. E-mail: rsamorim@ufv.br

3 Pós-Doutorando PNPD, PhD, Programa de Pós-Graduação em Agricultura Tropical, UFMT, Cuiabá, MT, Brasil. E-mail: hunter. maria@gmail.com

* Author for correspondence 
precipitação diária e elaboração da curva de permanência de três microbacias hidrográficas localizadas no município de Campo Verde-MT contemplando os seguintes usos: agricultura, pastagem e vegetação nativa. Essas bacias foram selecionadas estrategicamente por serem representativas dos principais sistemas de uso do solo na região de cerrado. Os resultados obtidos permitem ponderar que há diferença no regime hidrológico das microbacias hidrográficas ao longo do período analisado. As microbacias com vegetação nativa e com pastagem, por terem maior amplitude altimétrica, além de apresentarem solos de textura arenosa, são mais propensas à erosão hídrica. A microbacia com pastagem apresentou maior regularidade na vazão e, a microbacia com agricultura uma menor regularização do fluxo hidrológico em função das características físicas dos solos que compõe a microbacia.

Palavras-chave: Comportamento hidrológico. Coeficiente de escoamento. Manejo de bacias. Uso do solo.

\section{Introduction}

The use and occupation of soils in areas of the cerrado has increased greatly in the last decades, leading the alterations in the hydrologic dynamics of the system. These changes may provoke flash floods resulting in increased erosion, causing both environmental and socio-economic impacts (Graaf, 1996; Tucci, 1998). These alterations can be limited by researching management techniques that minimize the impact on the environment.

The cerrado biome covers 2 million $\mathrm{km}^{2}$ and $24 \%$ of the Brazilian territory. According to an Empresa Brasileira de Pesquisa Agropecuária [EMBRAPA], (2015) survey, the majority of this biome is undisturbed, with an estimated $54.5 \%$ intact. Planted pastures and agriculture occupy $29.4 \%$ and $11.6 \%$ respectively. These are the three most common land uses in the biome, though it is important to note that agriculture is increasingly common due to the flat terrain, suitable soils, and climate favorable to many crops.

Hydrologic dynamics of a basin can vary due to geomorphology (including the form, relief, area, geology, drainage patterns, soil, and others) and the type of vegetation (Lima, 1986). Many other factors also contribute, principally those related to land use that directly and indirectly contribute to infiltration, evapotranspiration and surface and subsurface runoff.

Existing research has quantified the increase in mean annual runoff due to decreases in vegetation cover in various ecosystems (Andréassian, 2004;
Bosch \& Hewlett, 1982; Brown, Zhang, McMahon, Western, \& Vertessy, 2005; Bruijnzeel, 1990; Dias, Macedo, Costa, Coe, \& Neill, 2015), though few of these studies were conducted in Brazil or within the cerrado biome. In the past decades the transformation to pasture and soybean within this region has also led to changes in the hydrological dynamics of water catchment basins.

Few studies have been conducted within the cerrado that focus on the hydrological dynamics of systems on the basis of use and management of soils, especially at the micro-basin level. Knowledge of natural mechanisms, as well as the effect of rainfall events on different land uses is of critical importance. Depending on a rainfall events intensity and duration it may result in high levels of erosion, and consequently sediment transport to stream channels. Schneider et al. (2014) note that it is important to identify the dynamics of transport within water basins as this helps land managers determine when new methods of land management may be necessary.

Changes in the hydrologic cycle of a water basins may occur from the moment of conversion from native vegetation to pastures (Grip, Fritsch, $\&$ Bruijnzeel, 2004). Changes in the local climatic characteristics alter the process of water transfer to the atmosphere (Díaz, Bigelow, \& Armesto, 2007). These factors, including incident solar radiation, evaporation, and precipitation, as well as others including lithology, relief, soil and vegetation cover drive the variability in the hydrologic regime according to Tucci (2002). 
A variety of studies on the hydrologic cycle have been conducted in the Brazil recently, mainly at the basin scale (Rocha \& Santos, 2018; Ávila, Mello, Pinto, \& Silva, 2014; Leli, Stevaux, Nóbrega, \& Souza, 2011; Nóbrega et al., 2017), that have contributed to the management of land use and planning for agricultural and conservationist practices. However, it is necessary that researchers take into account many factors, including climate, relief, soil and vegetation characteristics, and hydrologic dynamics at the micro-basin scale, especially changes in land use and management. These actions are necessary and fundamental for monitoring and controlling erosion, which is primarily influenced by the physical properties of soil such a texture, density and porosity (Silva, Schulz, \& Camargo, 2007). The objective of this research is to evaluate the morphometric characteristics of three hydrologic micro-basins, and the relationship between these characteristics and the hydrologic regime under three typical land uses (agriculture, pasture, and native vegetation) of the cerrado biome.

\section{Materials and Methods}

This research was conducted in three microbasins in the municipality of Campo Verde, in the state of Mato Grosso (Figure 1). These catchments are within the Rio das Mortes basin, one of the principal tributaries of the Araguaia River. The three micro-basins of interest are classified as first order and each has a spring that is protected by native vegetation around 180 meters from its outlet. These basins were selected strategically to represent the principal management and land uses of this region of the cerrado; Those under pasture and agriculture have $7 \%$ and $5 \%$ of native vegetation respectively. This region is characterized by intensive agriculture and ranching, with the following uses for the microbasins studied: traditional pasture with Braquiaria and 1 animal hectare ${ }^{-1}$ during the growth and finishing stages; annual crops of soy and corn in a successive cultures with direct planting, and; native vegetation of the cerrado biome, the reference of a non-developed environment.

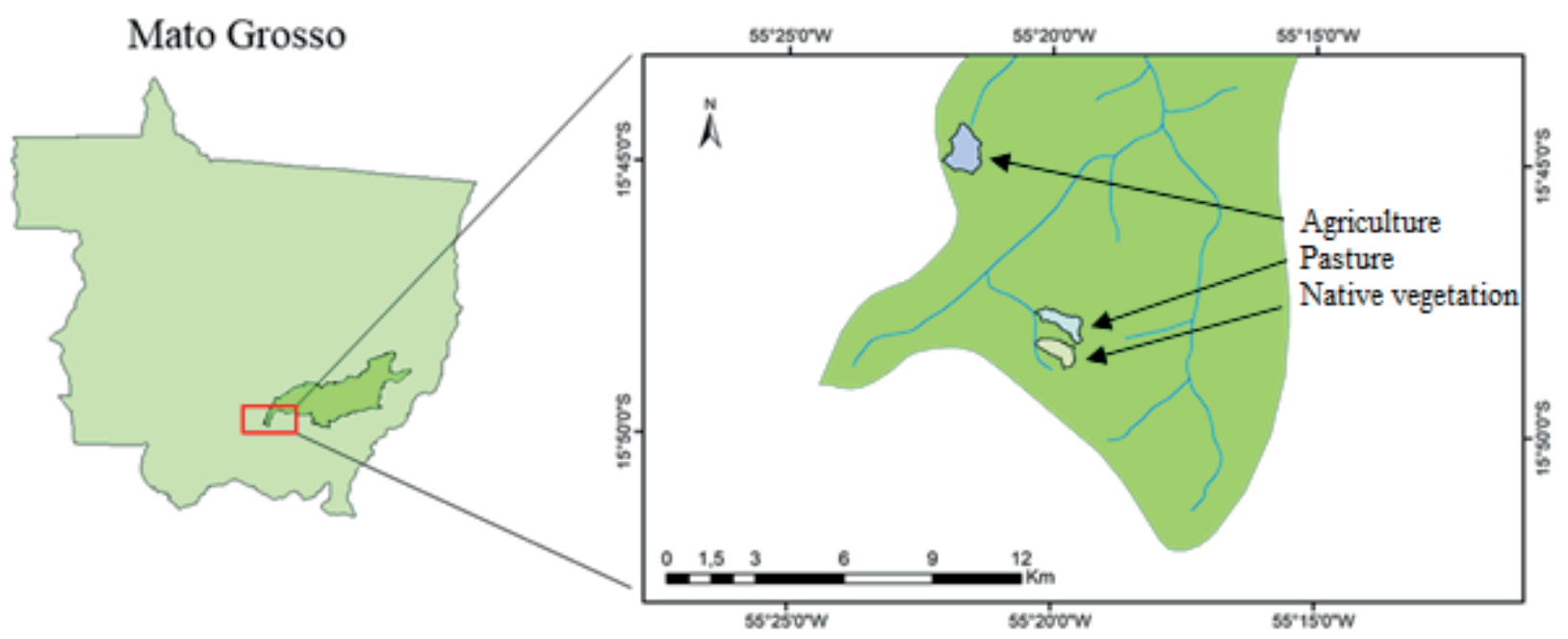

Figure 1. Location of study areas: Alto Rio das Mortes micro-basins in the state of Mato Grosso, Brazil. 
The climate of the region is classified following Köppen and Geiger as Tropical (Aw), with a mean annual temperature of $22.3^{\circ} \mathrm{C}$ and mean annual precipitation of $1,726 \mathrm{~mm}$. To better understand the hydrologic dynamics, rain gauges were installed in each of the micro-basins to measure the intensity of local precipitation. The data pertaining to daily precipitation during the period of the study, from August 2012 to November 2014, are shown in Figure 2.

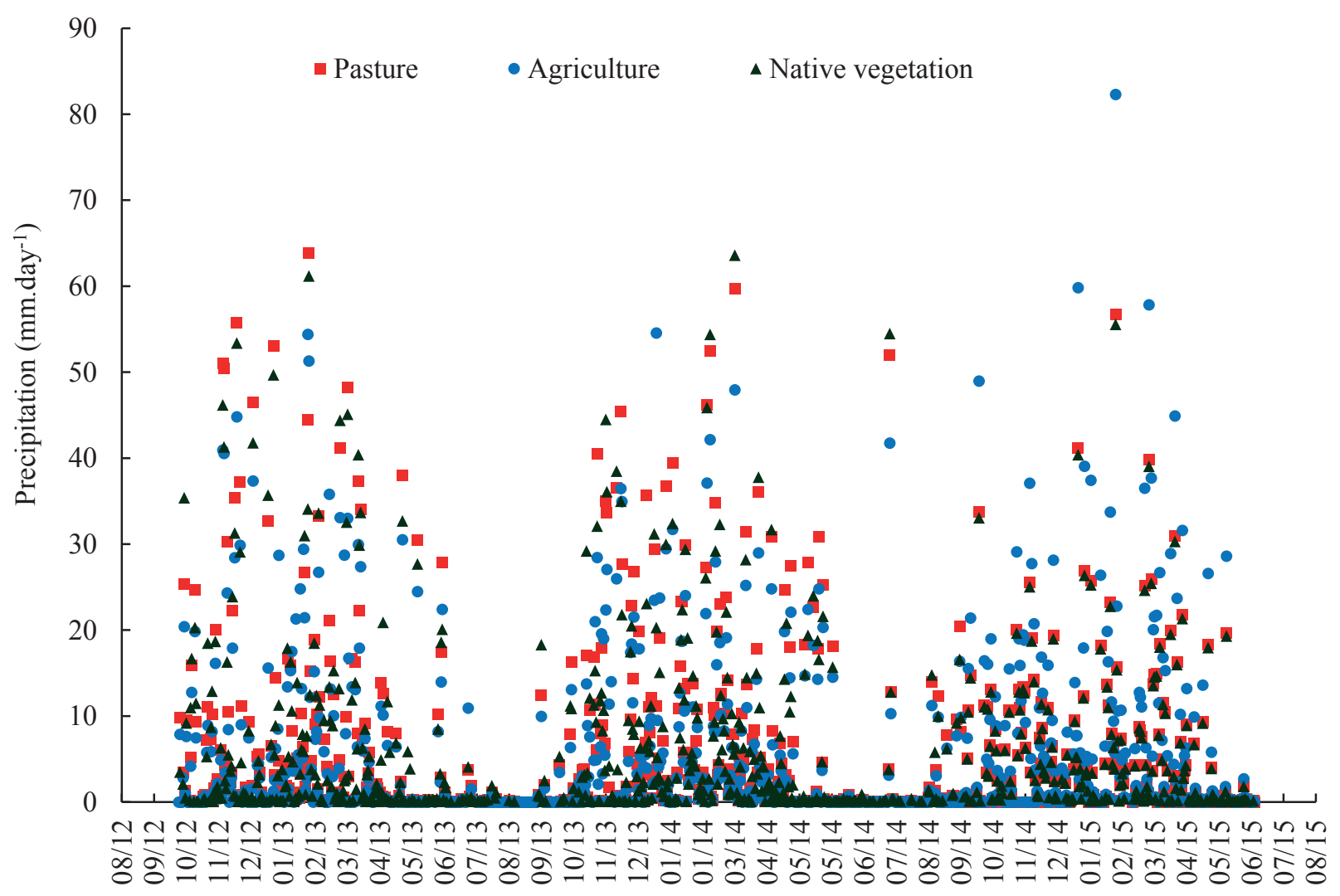

Period

Figure 2. Average daily precipitation data in each micro-basin (native vegetation, pasture and agriculture) in Campo Verde, state of Mato Grosso.

A detailed survey of altimetry was completed in the study region to delineate the catchment area of each basin using a precision GPS (TOPCON RTK Hiper Lite). With this survey, a digital elevation model (DEM) was generated, with 5 x 5 meter pixels. Using automated delineation of the basin, morphometric characteristics of the microbasins were determined following Tonello (2005) including: compactness coefficient, form factor, and circularity index.
The compactness coefficient (Kc) or Gravelius index is the relationship between the perimeter of the basin and the circumference of a circle of equal area (Villela \& Mattos, 1975). The size of the basin does not influence this coefficient, but rather the shape will result in different values of Kc. Values close to 1 are related to circular basins that are more prone to flooding, whereas values above 1 relates to basins that are irregular or elongated in shape and have lower likelihood of flooding (Souza, Cardoso, 
Souza, Santos, \& Santos, 2015). The compactness coefficient was calculated following Equation 1 (Villela \& Mattos, 1975):

$$
K c=0,28 \frac{P}{\sqrt{A}}
$$

where $\mathrm{Kc}$ is the compactness coefficient, $\mathrm{P}$ is the perimeter $(\mathrm{km})$ and $\mathrm{A}$ is the area of the basin $\left(\mathrm{km}^{2}\right)$, (Villela \& Mattos, 1975).

The form factor (FF) is the relationship between the mean width of the basin and the longest path from the spring to the basin edge. The closer this value is to one, the greater the susceptibility to flooding. The FF is calculated using Equation 2 (Horton, 1945):

$$
F F=\frac{A}{L^{2}}
$$

where $\mathrm{FF}$ is the form factor, $\mathrm{A}$ is the area of the basin $\left(\mathrm{km}^{2}\right)$ and $\mathrm{L}$ is the length of the longest axis $(\mathrm{km})$.

The circularity index (Ci), was determined following Cardoso, Dias, Soares and Martins (2006), and is the relationship between the perimeter and the area of the basin, wherein values approach unity for circular basins and decrease for elongated basins. The $\mathrm{Ci}$ was calculated using Equation 3 (Schumm, 1956):

$$
C i=12,57 \times\left(\frac{A}{P^{2}}\right)
$$

where $\mathrm{Ci}$ is the circularity index, $\mathrm{A}$ is the area of the basin $\left(\mathrm{km}^{2}\right)$ and $\mathrm{P}$ is the perimeter of the basin.

In each of the micro-basins were collected disturbed and undisturbed samples at $0-0.20 \mathrm{~m}$, $0.2-0.4 \mathrm{~m}$, and $0.4-0.6 \mathrm{~m}$, within a sampling grid of $200 \times 120 \mathrm{~m}$. Disturbed samples were oven dried with forced air $(60 \mathrm{C})$ for 48 hours. After drying, samples were sifted with a $2 \mathrm{~mm}$ sieve and properly stored. In these samples quantities of sand, silt and clay were determined using the pipette method as described by Donagema, Campos, Calderano, Teixeira and Viana (2011) with modifications suggested by Ruiz (2005). The total organic carbon (TOC) was determined using an Leco CHN 628 Elemental Analyser. This equipment determines carbon in the form of $\mathrm{CO}_{2}$ through optimized nondispersive infrared (NDIR) cells. Undisturbed samples were saturated using liquid surface elevation over 24 hours and then a matric potential ( $\Psi)$ of $-100 \mathrm{hPa}$ was applied using a tension table. After reaching equilibrium at a given tension, water content was determined. After the last measurement was made, the sample was oven dried at $105^{\circ} \mathrm{C}$ for 48 hours to determine total porosity, macroporosity, microporosity, soil moisture equivalent to field capacity and hydraulic conductivity as presented in Table 1. 
Table 1

Physical and physical-hydric attributes of soils studied in the three micro-basins, in Campo Verde, state of Mato Grosso

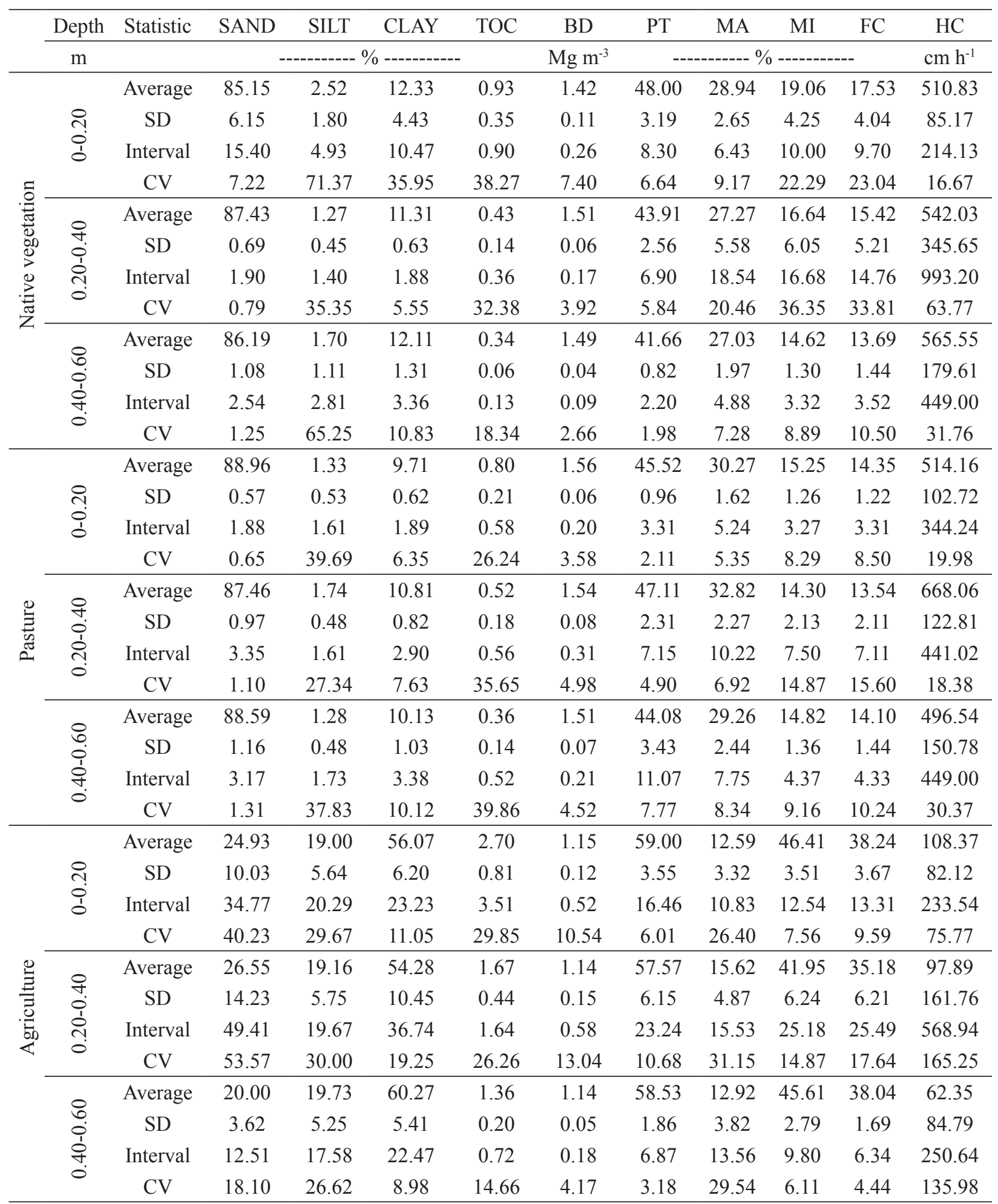

Subtitle - TOC: total organic carbon; BD: bulk density; PT: total porosity; MA: macroporosity; MI: microporosity; FC: field capacity; HC: hydraulic conductivity; CV: coefficient of variation; SD: standard deviation. 
To monitor outflow, convergence points for surface water were identified in the three microbasins studied and flow measurement stations were installed. To monitor flow in each control section, a triangular spillway and a level sensor to continually register the surface level over a Parshall flume were installed. Flow was calculated based on the water height and the calibration curve of the Parshall flume.

\section{Results and Discussion}

The morphometric characteristics of each microbasin are presented in Table 2, with values for the form factor (FF), compactness coefficient $(\mathrm{Kc})$, and circularity index (Ci). Within the areas studied, the agricultural micro-basin has the largest area of $1.35 \mathrm{~km}^{2}$, resulting in the largest catchment area and consequently larger amounts of precipitation entering the system when compared to the microbasins with native vegetation or pasture. Considering the form factor, the agricultural area has a factor of
0.51 , greater than either other area. Small values of FF are related to longer basins that are less subject to flooding due to longer water concentration times and lower probability of the entire basin receiving water from the same rainfall event. In general, only basins with FF higher than 0.75 are prone to large floods (Villela \& Mattos, 1975).

The compactness coefficient in all micro-basins was greater than 1.5, which following Souza et al. (2015) indicates low risk of flash flooding. The micro-basin with native vegetation showed higher values for the compactness coefficient (2.07) whereas the pasture and agricultural micro-basins showed lower values of 1.57 and 1.68 respectively. The circularity index, that relates the perimeter to the area of the basin, shows comparatively larger values were found for the micro-basin with pasture, followed by those with agriculture and native vegetation. Values of this ratio tend toward one for circle-shaped basins, and decrease as the basin becomes more elongated (Cardoso et al., 2006).

Table 2

Morphometric characteristics of micro-basins with the components of agriculture, pasture and native vegetation in Campo Verde, state of Mato Grosso

\begin{tabular}{cccccc}
\hline Micro-basin & Area & Perimeter & FF & Kc & Ci \\
\hline Native vegetation & $\mathrm{km}^{2}$ & $\mathrm{~km}$ & \multicolumn{2}{c}{-------- dimensionless ---------- } \\
Agriculture & 0,79 & 7,0 & 0,23 & 2,07 & 0,23 \\
Pasture & 1,35 & 4,3 & 0,51 & 1,68 & 0,34 \\
\hline
\end{tabular}

Subtitle - FF: Form factor; Kc: Compactness coefficient; Ci: circularity index.

It is important to note that the micro-basins with pasture and native vegetation have the same type of soil, quartzarenic Neossols, that are characterized by large quantities of sand in the soil profile (Table 1). According to Guimarães, Watanabe and Srinivasan (2000), the type of vegetation present in an area has a large influence on the surface runoff, and sediment production can be greatly reduced when soils are protected by native vegetation or mulch.
It is also important to note that the mean altimetric amplitude of these areas varies between 40 and 100 meters, with altitudes between 756 and $855 \mathrm{~m}$ (Table 3). The DEMs of the hydrographic micro-basins with agriculture, pasture and native vegetation are presented in Figure 3. 
Table 3

Descriptive statistics of the altimetry of microbasins with native vegetation, pasture and agriculture in Campo Verde, state of Mato Grosso

\begin{tabular}{|c|c|c|c|c|c|}
\hline Micro-basin & Average & Minimum & Maximum & SD & $\mathrm{CV}$ \\
\hline & --- & ------------ & - & & $\%$ \\
\hline Native vegetation & 807,96 & 756,60 & 854,07 & 29,13 & 3,60 \\
\hline Pasture & 813,53 & 771,55 & 855,24 & 23,69 & 2,91 \\
\hline Agriculture & 785,60 & 770,77 & 801.74 & 8,32 & 1,06 \\
\hline
\end{tabular}

Subtitle - SD: standard deviation; CV: coefficient of variation.

Altimetric amplitude is a morphometric index that, together with slope and degree of dissection controls the potential energy available for the water droplet. As this value increases, the potential energy also increases as does the erosive capacity of the relief (Crepani et al., 2001; Moraes, 2016). In this sense, the micro-basin with native vegetation, followed by pasture, show relief more favorable to the erosive process when compared with the microbasin with agriculture. This helps explain why sandy and sloped areas are, in general, considered not proper for the cultivation of soy or corn. Producers of corn and soy prefer flatter areas with medium textured to clayey soils.

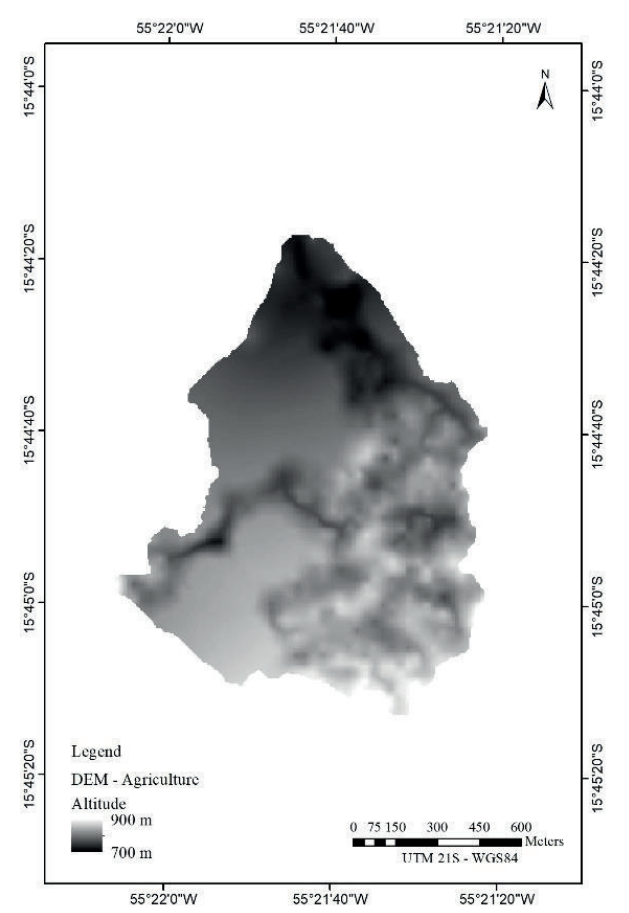

In Table 4 and Figure 4 is shown that changes in the hydrologic regime are not only in function of physiographic and morphometric characteristics but also in function of the land-use and soil cover of each micro-basin during the period of analysis. Note that in Table 4 the pasture micro-basin shows the largest measure of runoff per year (477.84 $\mathrm{mm}$ ), following by the micro-basin with native vegetation $(361.80 \mathrm{~mm})$ and by the micro-basin with agriculture $(141.32 \mathrm{~mm})$. It is also of note that the surface runoff coefficient within the pasture and native vegetation micro-basins were significantly higher than the micro-basin with agriculture in every month evaluated.

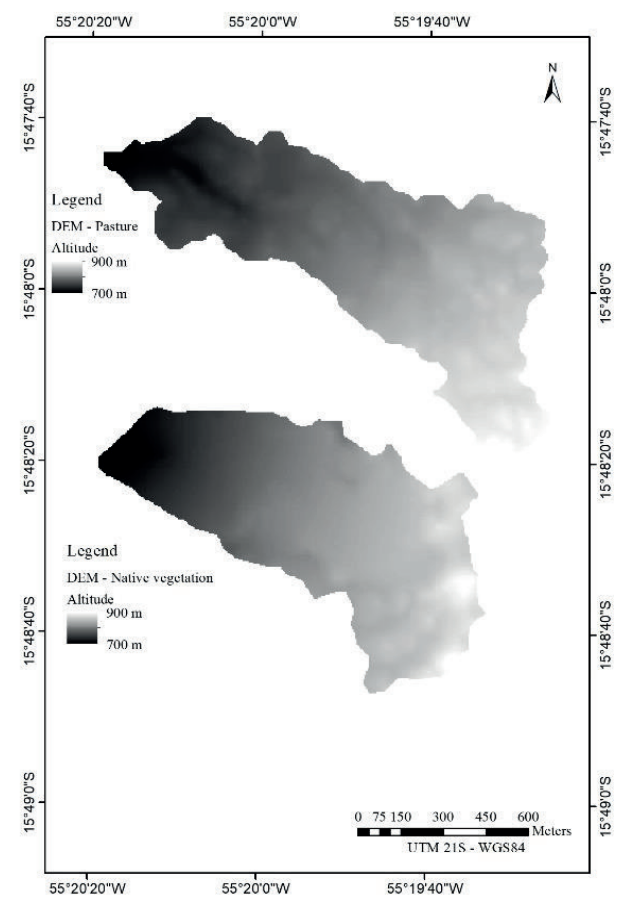

Figure 3. Digital elevation models (DEM) for hydrographic micro-basins with pasture, native vegetation and agriculture as the dominant land use, Campo Verde, state of Mato Grosso. 
Table 4

Precipitation, Flow and Runoff Coefficient (RC) data in micro-basins with native vegetation, pasture and agriculture component, Campo Verde, State of Mato Grosso, Brazil

\begin{tabular}{|c|c|c|c|c|c|c|}
\hline \multirow[b]{2}{*}{ Month } & \multicolumn{2}{|c|}{ Agriculture } & \multicolumn{2}{|c|}{ Pasture } & \multicolumn{2}{|c|}{ Native vegetation } \\
\hline & Precipitation & Flow rates & Precipitation & Flow rates & Precipitation & Flow rates \\
\hline & \multicolumn{6}{|c|}{----------------------------------------- mm ----------------------------------------- } \\
\hline Jan & 257.79 & 15.38 & 218.57 & 56.96 & 218.75 & 39.04 \\
\hline Feb & 244.22 & 17.57 & 244.04 & 52.17 & 244.31 & 41.56 \\
\hline Mar & 226.71 & 24.19 & 217.69 & 63.85 & 228.76 & 58.48 \\
\hline Apr & 148.51 & 20.10 & 138.36 & 59.44 & 128.93 & 49.30 \\
\hline May & 72.88 & 10.66 & 79.31 & 33.74 & 71.94 & 25.83 \\
\hline Jun & 36.17 & 10.95 & 35.19 & 37.51 & 32.64 & 27.07 \\
\hline Jul & 29.31 & 9.37 & 36.55 & 35.68 & 38.88 & 24.44 \\
\hline Aug & 1.57 & 4.94 & 2.05 & 9.90 & 2.40 & 13.83 \\
\hline Sep & 45.36 & 3.76 & 54.60 & 27.49 & 57.69 & 11.20 \\
\hline Oct & 154.15 & 7.23 & 145.93 & 25.86 & 150.19 & 23.28 \\
\hline Nov & 238.86 & 8.80 & 250.43 & 39.76 & 227.34 & 25.50 \\
\hline Dec & 185.32 & 8.36 & 194.08 & 35.50 & 177.49 & 22.28 \\
\hline Annual & 1640.85 & 141.32 & 1616.79 & 477.84 & 1579.33 & 361.80 \\
\hline $\mathrm{RC}$ & \multicolumn{2}{|c|}{0.09} & \multicolumn{2}{|c|}{0.30} & \multicolumn{2}{|c|}{0.23} \\
\hline
\end{tabular}

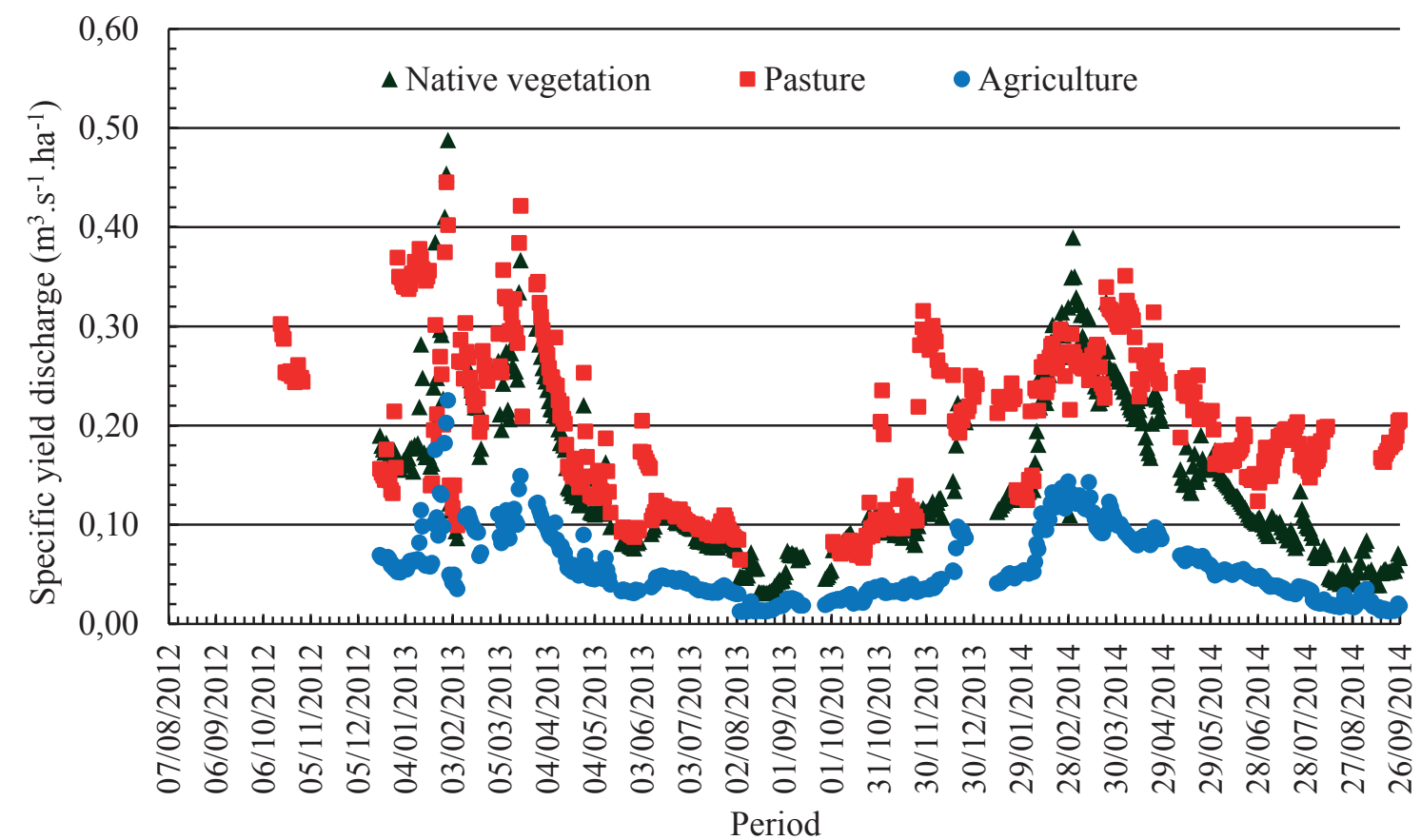

Figure 4. Specific yield discharge for micro-basins under land use of pasture, native vegetation and agriculture in the cerrado biome, Campo Verde, state of Mato Grosso, Brazil. 
In the cerrado and more specifically in the region of the Campo Verde municipality, the rainy season extends from October to April, and the dry season from May to September. During the rainy season observe four peaks of runoff (Figure 4) principally in the pasture and native vegetation micro-basins.

It is apparent that the differences between the micro-basins are not only in terms of their hydrology but also their soil characteristics. It is important to stress that knowledge of local hydrologic dynamics at the micro-basin scale can assist managers and owners of rural properties make decisions and potentially seek out new strategies for the management of soil, especially aiming to conserve not only soil, but water, and the ecosystem as a whole.

In Figure 4 it is apparent that the temporal variability of runoff imposes varying conditions for water use, allowing for greater use during high runoff volume periods and lower during drought, for all monitored basins. Monitoring specific yield discharge allows for spatial visualization of runoff (Tucci, 2000). Using this methodology it is observed that micro-basins with sandy soils tend to show runoff that has greater natural regularization, with a mean of $0.231 \mathrm{~m}^{3} \mathrm{~s}^{-1} \mathrm{ha}^{-1}$ and varying from $0.124 \mathrm{~m}^{3} \mathrm{~s}^{-1} \mathrm{ha}^{-1}$ to $0.431 \mathrm{~m}^{3} \mathrm{~s}^{-1} \mathrm{ha}^{-1}$ throughout the year, whereas the agriculture micro-basin has a mean runoff of $0.034 \mathrm{~m}^{3} \mathrm{~s}^{-1} \mathrm{ha}^{-1}$.

The flow duration curve relates runoff and the percentage of time that the flow is at or above a given level throughout the historical record (Cruz \& Tucci, 2008). As shown in Figure 5 the flow duration curve varied with the characteristics of each microbasin with greater intensity at the extremes of the graph of occurrence probability. The flow duration curves specific to the areas of native vegetation and pasture are not differentiable at high flow $\left(\mathrm{Q}_{10}\right)$, where the probability of higher flow is $10 \%$, reinforcing similarities between these two microbasins. However, all three basins show differences at low flow rates $\left(\mathrm{Q}_{90}\right.$ or $\left.\mathrm{Q}_{95}\right)$.

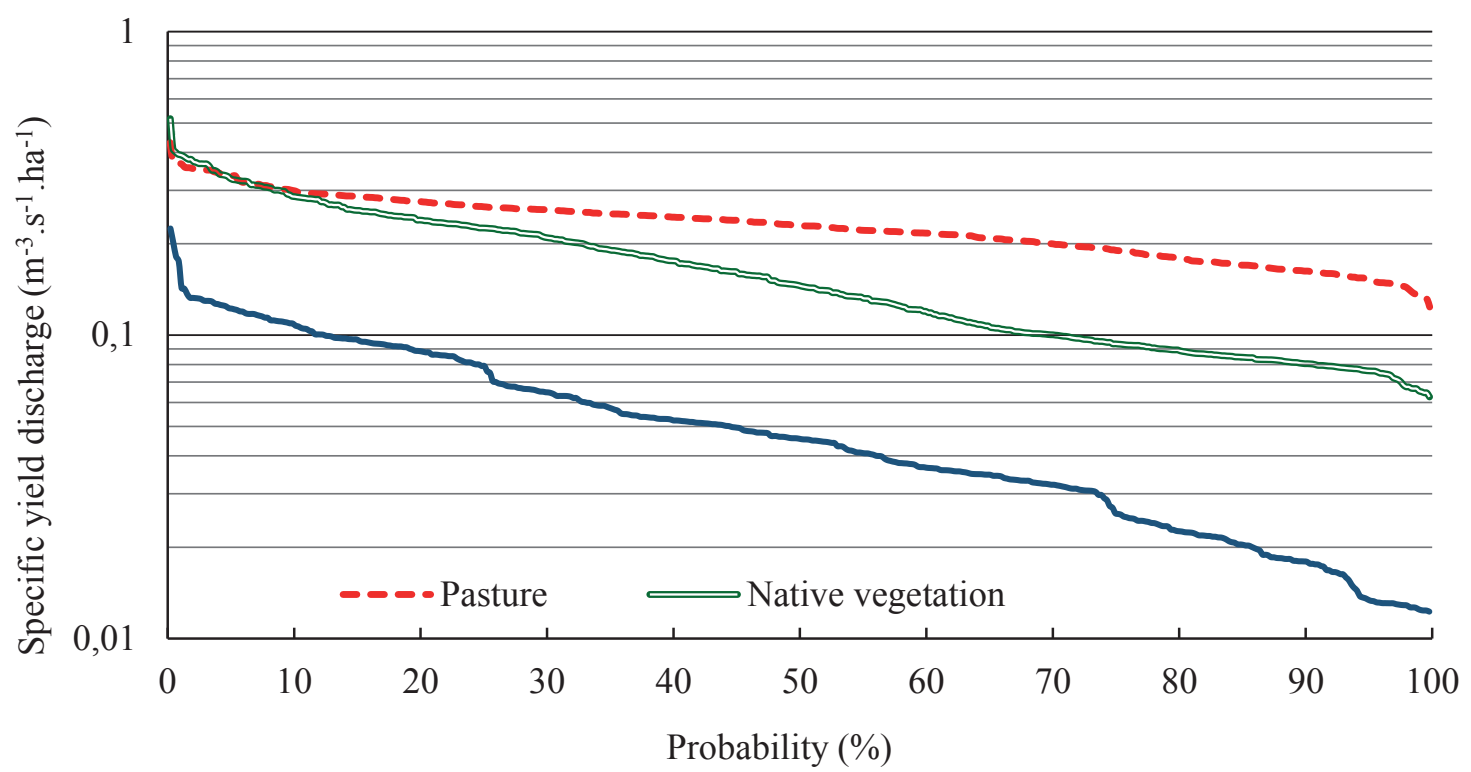

Figure 5. Permanence curves for micro-basins under land uses of pasture, native vegetation and agriculture in the cerrado biome, Campo Verde, state of Mato Grosso. 
According to Vestena, Oliveira, Cunha and Thomaz (2012), analysis of the flow duration curve allows for immediate visualization of the natural potential of the river, highlighting the minimum flow and the level of permanence of varying magnitudes of flows. Note that the pasture microbasin shows the highest natural regularization, and the agriculture micro-basin the lowest natural regularization. This is due to the morphometric characteristics of each basin, conditioned by factors including land use and the dynamics of water infiltration into the soil.

The agriculture micro-basin has clayey textured soils (Table 1), classified as Latossols, that may contribute to the limited natural regularization of the hydrologic flux. Soils of this type show higher water retention, limiting the outflow for this microbasin's outlet. The infiltration of water into the soil is a process that depends on many factors, but each at different levels. According to Rawls, David, Van Mullen and Ward (1996), these factors can be divided into those related to soils, those related to the ground surface, those related to management, and others. In the case of the micro-basins with pasture and native vegetation, both are characterized by sandy soils, with good permeability, and soil water infiltration (Bocuti, Amorim, Santos, Loreto, \& Pereira, 2019).

Dias et al. (2015) observed alterations in the hydrological dynamics of the Alto Xingu basin depending on the land use (soy, pasture and native vegetation). The authors observed that the conversion of native vegetation significantly altered evapotranspiration and increased the outflow in small hydrographic basins. However, in the basin with soybean cultivation, the mean outflow was three times higher, and the simulated evapotranspiration $39 \%$ lower when compared to the basins with native vegetation.

According to Tucci (2000), the role of the hydrographic basin is the transformation of an inflow that is concentrated in time (precipitation), into an outflow (runoff) that is most spread out over time. Nevertheless, this hydrological role will be greatly influenced by physical characteristics of the basins that include their drainage area, form, drainage system and relief.

Using the basin with native vegetation as a reference for undisturbed environment, we perceive the differences in the hydrological dynamics caused by pasture, as these two basins have the same soils. The variation in drainage along the period analyzed (Figure 4) and described by the flow permanence curve (Figure 5) can be related to the land use. The micro-basin characterized by native vegetation has dense tree coverage of species native to the region that result in high evapotranspiration when compared with pasture. This explains the measurable difference in the outflow; The native vegetation had a higher demand for water, reducing the amount of water available for outflow, and contributing to the lower natural regularization of the waterway. According to Best, Zhang, McMahom, Western and Vertessy (2003), evapotranspiration is the most important component of the hydrological cycle, greater than other factors such as recharge, surface runoff and variations in soil humidity. A study by Leopoldo, Franken, \& Villa Nova (1995) in central Amazonia, showed that $97 \%$ of total precipitation is only stored temporarily, without contributing to surface runoff and approximately $67.6 \%$ of precipitation is transpired.

It is important to remember than any alteration of an ecosystem, changing native vegetation for pasture and/or agriculture, may cause changes in local climate, changing the transportation of water to the atmosphere, and increasing the rate of surface runoff (Díaz et al., 2007; Li, Gu, Tan, \& Zhang, 2009; Grip et al., 2004).

Nóbrega et al. (2017) evaluated the effects of the conversion of native vegetation to pasture in the same study area as the current work. Authors observed that evapotranspiration was lower in the pasture area $\left(639 \pm 31 \% \mathrm{~mm} \mathrm{yr}^{-1}\right)$ when compared 
to the native vegetation of cerrado (1.004 $\pm 24 \%$ $\left.\mathrm{mm} \mathrm{yr}^{-1}\right)$, further noting the conversion from cerrado to pasture led to degradation of soil physical properties. Our results corroborate those of Nóbrega et al. (2017), showing the increase in the specific flow at the outflow during the dry season of the micro-basin with pasture, influenced by the low evapotranspiration of this system.

\section{Conclusions}

The micro-basins studied have form factor below one, related to irregular and elongated forms with low risk of flood.

The micro-basins with native vegetation and pasture have higher altimetric range, and despite having sandy soils show higher risk for erosion.

The pasture micro-basin showed greater regularization of flow, and the micro-basin with agriculture lower regularization of flow due to the physical characteristics of each micro-basin.

\section{Acknowledgements}

The authors thank the Fazenda Santa Luzia and the Fazenda Rancho do Sol for the use of the study areas. CAPES supplied the doctoral fellowship to the first author. This research was developed in partnership with the CarBioCial project (01 LL0902A). The authors also acknowledge the financial support of the Fundação de Amparo à Pesquisa do Estado de Mato Grosso (Research Support Fund of the State of Mato Grosso, www. fapemat.mt.gov.br; project: 335908/2012) and the Conselho Nacional Brasileiro de Desenvolvimento Científico e Tecnológico (Brazilian National Council for Scientific and Technological Advancement, www.cnpq.br; project: 481990/2013-5). The authors are particularly grateful towards their hosts during field work (the farms Santa Luzia and Rancho do Sol) and their field assistants Túlio G. Santos, Alan R. R. Martin and Gilmar N. Torres.

\section{References}

Andréassian, V. (2004). Waters and forests: from historical controversy to scientific debate. Journal of Hydrology, 291(1-2), 1-27. doi: 10.1016/j. jhydrol.2003.12.015

Ávila, L. F., Mello, C. R., Pinto, L. C., \& Silva, A. M. (2014). Participação da precipitação pluvial em uma microbacia hidrográfica ocupada por mata atlântica na serra da Mantiqueira, MG. Ciência Florestal, 24(3), 583-595. doi: 10.1590/1980-509820142403007

Best, A., Zhang, L., McMahom T., Western, A., \& Vertessy, R. (2003). A critical review of paired catchment studies with reference to seasonal flow and climatic variability. Australia: CSIRO Land and Water Technical.

Bocuti, E. D., Amorim, R. S. S., Santos, T. G., Loreto, L. A. L., \& Pereira, H. G. (2019). Erodibilidade entressulcos e sua relação com atributos de solos do Cerrado. Revista de Ciências Agrárias de Portugal, 42(1), 68-78. doi: 10.19084/RCA18130

Bosch, J. M., \& Hewlett, J. D. (1982). A review of catchment experiments to determine the effect of vegetation changes on water yield and evapotranspiration. Journal of Hydrology, 55(1-4), 3-23. doi: 10.1016/0022-1694(82)90117-2

Empresa Brasileira de Pesquisa Agropecuária (2015). Mapeamento inédito mostra uso e cobertura do Cerrado. Recuperado de https://www.embrapa.br/ busca-de-noticias/-/noticia/7808194/mapeamentoinedito- mostra-uso-e-cobertura-do-cerrado

Brown, A. E., Zhang, L., McMahon, T. A., Western, A. W., \& Vertessy, R. A. (2005). A review of paired catchment studies for determining changes in water yield resulting from alterations in vegetation. Journal of Hydrology, 310(1-4), 28-61. doi: 10.1016/j. jhydrol.2004.12.010

Bruijnzeel, L. A. (1990). Hydrology of moist forest and the effects of conversion: a state of knowledge review. Paris and Amsterdam: UNESCO. Retrieved from https://unesdoc.unesco.org/ark:/48223/pf 0000097405

Cardoso, C. A., Dias, H. C. T., Soares, C. P. B., \& Martins, S. V. (2006). Caracterização morfométrica da bacia hidrográfica do rio Debossan, Nova Friburgo, RJ. Revista Árvore [online],30(2), 241-248. doi: 10.1590/S0100-67622006000200011

Crepani, E., Medeiros, J. S., Hernandez, P., F ${ }^{\circ}$, Florenzano, T. G., Duarte, V., \& Barbosa, C. C. F. (2001). Sensoriamento remoto e geoprocessamento aplicados ao zoneamento ecológico econômico e ao 
ordenamento do território. São José dos Campos, SP: Instituto de Pesquisas Espaciais - INPE. Recuperado de http://sap.ccst.inpe.br/artigos/CrepaneEtAl.pdf

Cruz, J. C., \& Tucci, C. E. M. (2008). Estimativa da disponibilidade hídrica através da curva de permanência. Revista Brasileira de Recursos Hidricos, 13(1), 111-124. doi: 10.21168/rbrh.v13n1. p111-124

Dias, L. C. P., Macedo, M. N., Costa, M. H., Coe, M. T., \& Neill, C. (2015). Effects of land cover change on evapotranspiration and streamflow of small catchments in the Upper Xingu River Basin, Central Brazil. Journal of Hydrology: Regional Studies, 4(1), 108-122. doi: 10.1016/j.ejrh.2015.05.010

Díaz, F. M., Bigelow, S., \& Armesto, J. J. (2007). Alteration of the hydrologic cycle due to forest clearing and its consequences for rainforest succession. Forest Ecology and Management, 244(1-3), 32-40. doi: 10.1016/j.foreco.2007.03.030

Donagema, G. K., Campos, D. V. B., Calderano, S. B., Teixeira, W. G., \& Viana, J. H. M. (Org.). (2011). Manual de métodos de análise do solo (2a ed. rev.). (Documentos, 132). Rio de Janeiro: EMBRAPA Solos.

Graaf, J. (1996). The price of soil erosion. An economic evaluation of soil conservation and watershed development. Leiden, Netherlands: Netherlands Foundation for the Advancement of Tropical Research (WOTRO), Organization for Scientific Research (NWO), Project number W 45-104.

Grip, H., Fritsch, J. M., \& Bruijnzeel, L. A. (2004). Soil and water impacts during forest conversion and stabilisation of new land use. In M. Bonnell, \& L. A. Bruijnzeel (Eds.). Forests, water and people in the humid tropics (pp. 561-589). Cambridge: Cambridge University Press.

Guimarães, C.A., Suzuki, K., Watanabe, M., \& Srinivasan, V. (2000). Influência do tipo de cobertura vegetal sobre a erosão no semiárido paraibano. Revista Brasileira de Engenharia Agrícola e Ambiental, 4(1), 92-96. doi: 10.1590/S1415-43662000000100017

Horton, R. E. (1945). Erosional development of streams and their drainage basins; hydrophysical approach to quantitative morphology. Geological Society of América Bulletin, 56(3), 275-370. doi: 10.1130/0016-7606(1945)56[275:EDOSAT]2.0. $\mathrm{CO} ; 2$

Leli, I. T., Stevaux, J. C., Nóbrega, M. T., \& Souza, E. E., $F^{o}$. (2011). Variabilidade temporal no transporte de sedimentos no rio Ivaí - Paraná (1977-2007).
Revista Brasileira de Geociências, 41(4), 619-628. doi: 10.25249/0375-7536.2011414619628

Leopoldo, P. R., Franken, W. K., \& Villa Nova, N. A. (1995). Real evapotranspiration and transpiration through a tropical rain forest in central Amazônia as estimated by the water balance method. Forest Ecology and Management, 73(1-3), 185-195. doi: 10.1016/0378-1127(94)03487-H

Li, S., Gu, S., Tan, X., \& Zhang, Q. (2009). Water quality in the upper Han River basin, China: the impacts of land use/land cover in riparian buffer zone. Journal of Hazardous Materials, 165(1-3), 317-324. doi: 10.1016/j.jhazmat.2008.09.123

Lima, W. P. (1986). Principios de hidrologia florestal para o manejo de bacias hidrográficas. Piracicaba: ESALQ.

Moraes, I. C. (2016). Avaliação dos modelos de predição da erosão hídrica MEUPS e WEPP: contribuição em bacias hidrográficas. Tese de doutorado, Universidade Estadual Paulista "Júlio de Mesquita Filho", Rio Claro, SP, Brasil.

Nóbrega, R. L. B., Guzha, A. C., Torres, G. N., Kovacs, K., Lamparter, G., Amorim, R. S. S.,... Gerold, G. (2017). Effects of conversion of native cerrado vegetation to pasture on soil hydro-physical properties, evapotranspiration and streamflow on the Amazonian agricultural frontier. Plos One, 12(6), 1-22. doi: 10.1371/journal.pone.0179414

Rawls, W. J., David, G., Van Mullen, J. A., \& Ward, T. J. (1996). Infiltration. In ASCE. Hydrology Handbook. 2a ed. Manuals and Report on Engineering Practice. (pp. 75-124) New York: ASCE.

Rocha, P. C., \& Santos, A. A. (2018). Análise hidrológica em bacias hidrográficas. Mercator, 17(17025), 1-18. doi: 10.4215/rm2018.e17025

Ruiz, H. A. (2005). Incremento da exatidão da análise granulométrica do solo por meio da coleta da suspensão (silte+argila). Revista Brasileira de Ciência do Solo, 29(2), 297-300. doi: 10.1590/ S0100-06832005000200015

Schneider, R. M., Freire, R., Boina, W. L. O., Cossich, E. S., Soares, P. F., \& Tavares, C. R. G. (2014). Assessment of turbidity as a quick tool to quantify the sediment transport. Revista Nativa, 2(1), 32-36. doi: 10.14583/2318-7670.v02n01a06

Schumm, S. A. (1956). Evolution of drainage systems and slopes in badlands of Perth Amboy, New Jersey. Geological Society of America Bulletin, 67(5), 597-646. doi: 10.1130/0016-7606(1956)67[597: EODSAS]2.0.CO 
Silva, A. M., Schulz, H. E., \& Camargo, P. B. (2007). Erosão e hidrossedimentologia em bacias hidrográficas (2a ed.). São Carlos: Rima.

Souza, N. S., Cardoso, J. M. S., Souza, W. J., Santos, J. Y. G., \& Santos, P. S. (2015). Anais de Simpósio Brasileiro de Sensoriamento Remoto - SBSR, João Pessoa, PB, Brasil, 17.

Tonello, K. C. (2005) Análise hidroambiental da bacia hidrográfica da cachoeira das pombas, Guanhães, $M G$. Tese de doutorado, Universidade Federal de Viçosa, Viçosa, MG, Brasil.
Tucci, C. E. M. (1998). Modelos hidrológicos. Porto Alegre: ABRH/UFRGS.

Tucci, C. E. M. (2002) Regionalização de vazões. Rio Grande do Sul: Ed. Universidade, UFRGS.

Vestena, L. R., Oliveira, E. D., Cunha, M. C., \& Thomaz, E. L. (2012). Vazão ecológica e disponibilidade hídrica na bacia das Pedras, Guarapuava-PR. Revista Ambiente \& Água, 7(3), 212-227. doi: 10.4136/ ambi-agua. 840

Villela, S. M., \& Mattos, A. (1975) Hidrologia aplicada. São Paulo: McGraw-Hill. 